\title{
Form the Optimal Investment Portfolio Applied Study in the Jordanian Banking Sector (2013-2017)
}

\author{
Suleiman Daood Al-Oshaibat ${ }^{1}$ \\ ${ }^{1}$ Assistance professor, Faculty of Business, Tafila Technical University, Tafila, Jordan \\ Correspondence: Suleiman Daood Al-Oshaibat, Assistance professor, Faculty of Business, Tafila Technical \\ University, Tafila, Jordan.
}

Received: November 21, 2019

Accepted: January 9, 2020

Online Published: February 10, 2020

doi:10.5539/ibr.v13n3p79

URL: https://doi.org/10.5539/ibr.v13n3p79

\begin{abstract}
The study aimed to form the optimal investment portfolio in the Jordanian banking sector. The research covered a period (2013-2017) and the sample of the study was selected from its community of Jordanian banks listed on the Amman Stock Exchange, consisting of (15) working banks for which the necessary data are available to study.

The importance of the research lies in the formation of a thought and methodology that can be applied and utilized by investors and securities analysts in the management of their investment portfolio.

The study shows that the effective rate of return is higher than the required rate of return in the Jordanian commercial banks. This indicates that the commercial banks have succeeded in their estimates of the required or actual rate of return for the optimal investment portfolio banks. the correlation matrix between returns on each bank in the investment portfolio is mostly low, which confirms that the investment portfolio of Jordanian banks is efficient, as Markowitz stressed on his focus on the correlation coefficient between returns and its impact on the return and risk of the optimal investment portfolio that achieve the highest return at a certain level of risk.
\end{abstract}

Keywords: portfolio, return, risk

\section{Introduction}

The investment projects implemented in fluctuated environment that effect on all economics activities, such as interest rate and inflation, so the current study raises the question how to build the optimal investment portfolio in Jordanian banking sector, due to its important role in supporting the different economic sectors and beneficiaries of finance. The aim is to attract investors that seek to achieve the maximum return at a certain given level of risk or minimize risk at a given level of returns with leading to increase profit.

The importance of this study is how to reduce the systemic risks, which affect all economic sectors in light of the high uncertainty and volatility of financial markets. The commercial banks sector in Jordan is operating in a weak financial market characterized by high investment risks in it, while the research aims to present how to form an optimal investment portfolio with the aim to achieve the required returns and risks.

\section{Theoretical Framework}

Diversification is the process of allocating capital in a way that reduces the exposure to any one particular asset or risk. A common path towards diversification is to reduce risk or volatility by investing in a variety of assets (Johnson, 2000, 119)

Besides, diversification also allocates investment capital to a range of assets to increase returns and reduce risk (Ross, et.al, 1996,286), while Carlson (1998: 86) describes it as a process of reducing risk by forming portfolios of financial and in-kind instruments with associated returns. Incomplete, Markowitz defines diversification as associated assets that are less than fully correlated to minimize risk without sacrificing portfolio returns (Francis, 1991: 234).

According to Markowitz (1952), efficiently diversified portfolios are those which maximize return for a given level of risk or minimize risk for a given level of return for different correlation coefficients. The correlation coefficient is a relative measure of changes with a suitable probability that reflects the variance and always represents an absolute number between +-1 .If the returns from investments are independent, there is no observable relationship between the variables and knowledge of that the one is used for predicting the other. The 
variance of the two investments combined will equal the sum of the individual variances,. i.e. the covariance is zero if returns are certified:

- A perfect positive, correlation of (+1) means that whatever affects one variable will equally affect the other. Diversified risk-reduction is not possible.

- A perfect negative correlation of (-1) means that an efficient portfolio can be constructed, with zero variance exhibiting minimum risk. If one investment will produce a return above its expected return, the other will produce an equivalent return below its expected return and vice versa. Between +1 and -1 the correlation coefficient is determined by the proximity of direct and inverse relationships between individual returns So, in terms of risk reduction, even a low positive correlation can be beneficial to investors, depending on the allocation of total funds at their disposal (Robert Alan, Hill, 2010:28)

Several studies have examined how to optimize the investment portfolio, including Eichholtz, 2003 entitled "International Diversification of Investment in Real Estate and Securities Stocks and Bonds" aimed at reducing risks by international diversification. The research was carried out on a sample of eleven countries: Belgium, France, Italy, the Netherlands, Britain, Australia, Hong Kong, Japan, Singapore, Canada, and the United States. This study has shown that the correlations between the proceeds of real estate are less than the correlations between the returns of equities and bonds, so investment in property is cheaper. The study reached the following conclusion: The international diversification of investment in real estate is better than the investment in stocks and bonds.

A study of "Nugroho and Rachmat, 2013" entitled "Portfolio determination and Markowitz efficient in five Indonesian industrial sector" aimed to build an optimal and effective portfolio of companies listed on the Indonesia Stock Exchange during the period (2011-2011). The study formed (3) first governorates containing the largest Companies in terms of market returns and the second portfolio include less than (5) companies from Where the overall risk, the third contain the best (5) companies in terms of return on rights. The study evaluated the performance of these portfolios through models (Jensen, Treynor, Sharp) and found that the first portfolio performs better than the market portfolio and other portfolios according to Jensen, sharp and the third portfolio are better according to Treynor model. The study recommended that investors in Indonesia should rely on market share returns when deciding to invest in the stock market.

The study presented by Hassan et al. 2010 aimed to provide an overview of the international diversification of the portfolio and its impact on the characteristics of the investment portfolio, by presenting a series of studies in this area. In the context of the study, the research was purely theoretical and dictated a set of conclusions on the subject. These studies have shown a low correlation between International financial markets, highlighting the significant gains of international diversification.

Al-Hasanat Study (2013) included population dealt with all the shares of listed companies. The beta model based on the Trinor Index, free-market index, Sharp index and market-weighted index to determine the preferred candidate stocks for the optimal portfolio and the design of alternative portfolios, and during the period of time (2001-2009). The most important characteristic is that it urges the managers of the portfolio to maintain a number of characteristics of the company along with the historical aspect of the movement of share prices, and the degree of risk, and the factors that contributed to achieve different returns and risks to be included in the optimal portfolio.

Tamimi and Janabi, 2003 aimed to designe the optimal and alternative common stock portfolio, an Sample listed in the Iraqi stock market, as was selected a random sample consisting of 12 companies, industrial out of 34 companies, One agricultural company out of 17 companies, and two of the services sector out of 33 companies, The aim of the study was to use a scientific method that serves the Iraqi investor when designing his portfolio of ordinary shares in the light of an objective exchange between return and risk. Linearprogramming has been adopted to achieve this, and the most important results to reach is the design of five portfolios of alternative portfolio optimal, which suit different investment behaviors, and these portfolios that vary in terms of the levels of risk and return, as noted that it has formed a three portfolios yield and risk less than Return Risk of optimal investment portfolio, with the return of the three alternative portfolios at $19.6 \%, 17 \%, 17.43 \%$, respectively, against the risk measured by the beta factor $0.43,0.49$ and 0.87 , respectively.

Houari and Malik, 2013 studed the contribution of international diversification in the effective management of the financial portfolios through reducing risk, and realizing a better relationship between return and risk of the portfolio, and the possibility to take advantage of it under the hedging exchange risk. On this basis, it has been selected and configured a sample study from group of indices in the stock exchanges for the period between 03/06/2010- 04/17/2013 where the analysis and statistical are used. The study concluded that the correlation 
coefficient and the relative weight of the asset, and hedge exchange risk are key determinants to improve the characteristics of the international portfolio, thus contributing to the effective management of the financial portfolio.

Investors always seek to achieve the highest return as the main driver behind the movement of capital and transfer from the other hand and from one country to another as capital always tends towards better profitability. (Ani 2002: 76). There are four types of returns:

-Return on asset: This ratio measures the efficiency of management in the use of assets to make the best use of profits during the process of investment in the assets. This ratio can be calculated according to the following formula (Michael \& Ehrhardt 2005:454):

-Return on assets $=$ Earnings before interest and taxes $/$ total assets

$\mathrm{ROA}=\mathrm{EBIT} / \mathrm{Total}$ assets

- Return on Equity: This rate reflects the efficiency of the institution in the use of its own resources through the ability of these resources to generate profits and is measured according to the following formula: (Bodie \& kane; 569: 199)

\section{ROE=EBTI/Total Equity}

- Actual Return: It is the return that the investor actually receives and can be calculated according to the following equation: (Mc.menamin 1999: 187)

$$
\mathrm{R}=\mathrm{P} 1-\mathrm{P} 0+\mathrm{D} / \mathrm{P} 0
$$

Whereas:

R: Actual rate of return

P1: Share price at the end of the period

P0: Share price at the beginning of the period

D: Dividends

- Required rate of return: $t$ is the expected return of the security that is sought by the investor and is achieved according to the variables of risk free return and the degree of systematic risks to which the investor is exposed and the return of the capital market portfolio based on the capital asset pricing model(CAPM).

The following formula can be applied: "Michael \& Ehrhardt, 2005: 237"

$$
R j=R f+(R m-R f) \quad j
$$

Whereas:-

Ri: The required rate of return for an ordinary stock

Rf: risk free rate

Rm: Market portfolio return

Bj: beta coefficient (systemic risk measure)

Relevant Arab and foreign sources have been relied on to enrich the theoretical aspect of the research. The various financial statements of commercial banks (balance sheet and income statement) were utilized through the financial statements published on the Amman Stock Exchange. The official interest set in the Jordanian commercial banks (10\%), where the following statistical measures were also used for research purposes:

Arithmetic Mean: to determine the level of data is measured as follows: Arithmetic Mean

$$
\text { 'X }=\sum x i / n
$$

Where $\mathrm{X}$ is the mean, $\mathrm{n}$ is the number of years and $\mathrm{xi}$ is the sum of the data.

$$
\text { Person coefficient: } r_{\mathrm{X}} \mathrm{y}=
$$

$$
\frac{\mathrm{n} x_{i} y_{i}-x_{i} \quad y_{i}}{\sqrt{\left(n \sum x_{i}^{2}-\sum x_{i}\right)^{2}\left(n \sum y_{i}{ }^{2}-\sum y_{i}\right)^{2}}}
$$

Variance and Standard deviation: variance $=\mathrm{S} 2=\left[\sum\left(\mathrm{xi}-^{-} \mathrm{X}\right)\right.$ 2] $] / \mathrm{n}$

Where the standard deviation is the square root of the variance. 
Coefficient of variation: This refers to the risk per unit of return resulting in a meaningful comparison when the expected return on investment alternatives is not equal and is measured as follows (Chong, 2004: 92).

$$
\text { Coefficient of variation }=\text { C.V. }(\mathrm{A})=\quad / \mathrm{R} \times 100
$$

Where $\quad=$ standard deviation and $\mathrm{R}$ is the average yield

\section{Beta coefficient}

It measures the systemic risk of assets and measures the risk of a stock to market risk and can be calculated according to the following equation (Copleland \& Waston, 1988: 164).

$$
\beta=\frac{\operatorname{cov}(R i R m)}{v R m}
$$

Whereas:

Cov $(\mathrm{r}, \mathrm{m})$ : Covariance or covariance between return on assets and earnings per share

$\operatorname{Var}(\mathrm{m})$ : Market return variation: The risk of two-assets for market portfolio can be calculated according to the following formula:

$$
(\mathrm{P})=\operatorname{VAR}(\mathrm{P})=\left[x^{2} \operatorname{VAR}(\mathrm{A})+(1-x)^{2} \operatorname{VAR}(\mathrm{B})+2 x(1-x) \operatorname{COR}(\mathrm{A}, \mathrm{B}) \quad \mathrm{A} \quad \mathrm{B}\right]
$$

\subsection{Construction of the Optimal Portfolio}

In order to select the optimal investment portfolio sought by investors should start by identifying a sufficient number of portfolios and there is a trend representing a group of portfolios called the efficient investment curve, which is a trend that represents a group of portfolios that have the highest return at a certain level of risk or the lowest risk at a certain level of Returns (Robert Alan Hill, 2010) As shown in figure 1, investors will focus on the upper boundary along this trend and therefore the conservative along this efficient line is effective or efficient because it produces an expected return at a certain level of risk and here must take into account the positions of investors risk.

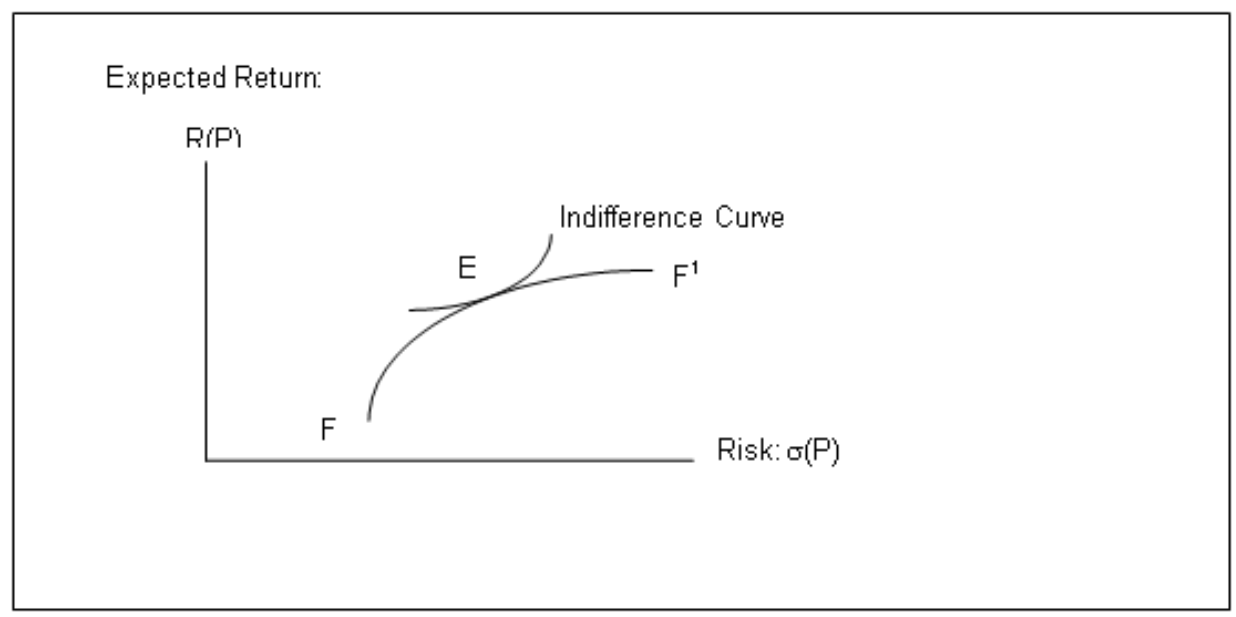

Figure 1. the determination of an optimum portfolio

Therefore, the optimal portfolio is at point $(\mathrm{E})$, which crosses both the trend which reflects the preferences of investors and the border efficiency approach because this point gives the best combination of returns and risks.D

\subsection{Analysis}

In order to select the optimal investment portfolio from among the investment portfolios of commercial banks included in the research below is a discussion of these investment portfolios for the period (2013-2017).

\subsubsection{Results of Return on Equity Analysis for Commercial Banks}

Table 1 shows the rate of return on the right of ownership in the commercial banking sector in Jordan for the years (2013-2017). Arab Investment Bank (0.10) followed by Union and Investment Banks (0.9) followed by Jordan Kuwait Bank (JKB) and Jordan Capital Bank (0.8) and Arab Bank and Jordan Bank (0.7).

As for the standard deviation, all banks had less than (1) and zero at the following banks: Jordan Commercial Bank, Housing Bank, Arab Banking and Investment Bank. 
Table 1. The required rate of return on equity in the commercial banking sector for the years (2013-2017)

\begin{tabular}{|l|l|l|l|l|l|l|l|}
\hline Bank name & 2013 & 2014 & 2015 & 2016 & 2017 & mean & S.D \\
\hline Jordan Islamic Bank & 0.18 & 0.16 & 0.16 & 0.16 & 0.14 & 0.16 & 0.01 \\
\hline Jordanian Kuwaiti & 0.12 & 0.11 & 0.09 & 0.06 & 0.06 & 0.08 & 0.03 \\
\hline Jordan Commercial & 0.00 & 0.01 & 0.01 & 0.01 & 0.00 & 0.01 & 0.00 \\
\hline Housing Bank & 0.01 & 0.02 & 0.02 & 0.02 & 0.02 & 0.02 & 0.00 \\
\hline Arab Investment & 0.10 & 0.11 & 0.10 & 0.10 & 0.08 & 0.10 & 0.01 \\
\hline Safwa Islamic & 0.01 & 0.01 & 0.02 & 0.04 & 0.04 & 0.03 & 0.01 \\
\hline the Union & 0.09 & 0.10 & 0.10 & 0.09 & 0.08 & 0.09 & 0.01 \\
\hline $\begin{array}{l}\text { Arab } \text { Corporation } \\
\text { Investment Bank }\end{array}$ & 0.01 & 0.01 & 0.02 & 0.01 & 0.01 & 0.01 & 0.00 \\
\hline Capital Bank & 0.09 & 0.08 & 0.09 & 0.09 & 0.09 & 0.09 & 0.00 \\
\hline Société & 0.11 & 0.11 & 0.00 & 0.05 & 0.08 & 0.08 & 0.05 \\
\hline Cairo Amman & 0.06 & 0.08 & 0.08 & 0.08 & 0.06 & 0.07 & 0.01 \\
\hline Jordan Bank & 0.15 & 0.15 & 0.13 & 0.10 & 0.09 & 0.12 & 0.03 \\
\hline Ahli Jordan & 0.11 & 0.13 & 0.11 & 0.10 & 0.10 & 0.11 & 0.01 \\
\hline Arab Bank & 0.06 & 0.11 & 0.07 & 0.02 & 0.04 & 0.05 & 0.03 \\
\hline Market Index & 0.09 & 0.06 & 0.04 & 0.06 & 0.05 & 0.07 & 0.02 \\
\hline
\end{tabular}

2.2.2 The Results of the Analysis of the Effective Rate of Return and the Rate of Return Required for Commercial Banks

It is noticeable from Table 2 that the results of the general average of (0.7) have been moved away from Safwa Islamic Bank (3.36), Jordan Capital Bank (2.05) and Bank Societe (2.11) the rest of the banks came below the general average of (0.7), the average standard deviation was 1.03. All commercial banks came lower than this rate except for the following commercial banks: Safwa Islamic Bank, Jordan Capital Bank and Societe Bank which exceeded this rate, re $(4.25,3.95,5.08)$ respectively.

Table 2. Actual required rate of return on equity in the commercial banking sector for the years (2013-2017)

\begin{tabular}{|l|l|l|l|l|l|l|l|}
\hline Bank name & 2013 & 2014 & 2015 & 2016 & 2017 & mean & S.D \\
\hline Jordan Islamic Bank & 0.35 & 0.27 & 0.20 & 0.27 & 0.17 & 0.25 & 0.07 \\
\hline Jordanian Kuwaiti & 0.36 & 0.04 & 0.25 & 0.18 & 0.07 & 0.18 & 0.13 \\
\hline Jordan Commercial & 0.18 & 0.74 & 0.14 & 0.27 & 0.04 & 0.28 & 0.27 \\
\hline Housing Bank & 0.09 & 0.07 & 0.07 & 0.06 & 0.03 & 0.07 & 0.02 \\
\hline Arab Investment & 0.62 & 0.56 & 0.13 & 0.13 & 0.15 & 0.32 & 0.25 \\
\hline Safwa Islamic & 0.04 & 4.47 & 11.81 & 0.43 & 0.05 & 3.36 & 5.08 \\
\hline the Union & 0.32 & 0.70 & 0.15 & 0.42 & 0.10 & 0.34 & 0.24 \\
\hline $\begin{array}{l}\text { Arab } \text { Corporation } \\
\text { Investment Bank }\end{array}$ & 0.13 & 0.91 & 0.19 & 0.26 & 0.06 & 0.31 & 0.34 \\
\hline Capital Bank & 0.22 & 0.13 & 0.31 & 0.31 & 0.21 & 0.24 & 0.08 \\
\hline Société & 0.62 & 0.21 & 9.10 & 0.17 & 0.14 & 2.05 & 3.95 \\
\hline Cairo Amman & 0.07 & 0.40 & 9.71 & 0.11 & 0.24 & 2.11 & 4.25 \\
\hline Jordan Bank & 0.20 & 0.18 & 0.26 & 0.95 & 0.15 & 0.35 & 0.34 \\
\hline Ahli Jordan & 0.24 & 0.08 & 0.21 & 0.42 & 0.27 & 0.25 & 0.12 \\
\hline Arab Bank & 0.20 & 0.59 & 0.18 & 0.06 & 0.13 & 0.23 & 0.21 \\
\hline Market Index & 0.25 & 0.00 & 0.20 & 0.10 & 0.16 & 0.14 & 0.10 \\
\hline
\end{tabular}

As for the analysis of the effective rate of return and the required rate of return and comparison between them is shown in Table 3, which shows that the nominal average of its shares $(0.7)$, which is more than the general rate of return required rate of (0.07), which means that the management of banks has succeeded in Estimates of what is due from the required return and the effective rate of return of commercial banks constituting the investment portfolio. 
Table 3. Actual rate of return and required rate of return for the investment portfolio comprising the commercial banking sector for the years (2013-2017)

\begin{tabular}{|l|l|l|}
\hline Bank name & $\begin{array}{l}\text { The actual rate of return on } \\
\text { equity }\end{array}$ & The required rate of return on equity \\
\hline Jordan Islamic Bank & $\begin{array}{l}\text { The required rate of return } \\
\text { on equity }\end{array}$ & 0.159 \\
\hline Jordanian Kuwaiti & 0.18 & 0.082 \\
\hline Jordan Commercial & 0.28 & 0.006 \\
\hline Housing Bank & 0.07 & 0.016 \\
\hline Arab Investment & 0.32 & 0.100 \\
\hline Safwa Islamic & 3.36 & 0.031 \\
\hline the Union & 0.34 & 0.090 \\
\hline Arab Banking Corporation & 0.31 & 0.012 \\
\hline Investment Bank & 0.24 & 0.090 \\
\hline Capital Bank & 2.05 & 0.079 \\
\hline Société & 2.11 & 0.072 \\
\hline Cairo Amman & 0.35 & 0.120 \\
\hline Jordan Bank & 0.25 & 0.111 \\
\hline Ahli Jordan & 0.23 & 0.050 \\
\hline Arab Bank & 0.14 & 0.065 \\
\hline Market Index & 0.70 & 0.07 \\
\hline
\end{tabular}

\subsubsection{Selecting Banks According to Return, Risk and Required Rate of Return}

The investment portfolio will be selected on the basis of risk and return (measured in contrast) from the 15 banks and according to the conditions of forming an investment portfolio of efficient banks that achieve the highest return or that the degree of risk at these banks is lower than the risk of other securities. The optimal investment portfolio with the highest return at the lowest risk level.

It is noted that this portfolio achieved the highest return to reach (0.25), while in the previous portfolio was (0.07) and that the risk in this investment portfolio optimal (0.04), which is lower than the previous portfolio of (1.03) and The required rate of return was $(0.08)$ which is less than the actual rate of return in the previous portfolio (0.7), which means the possibility of obtaining an optimal investment portfolio better than this by adding other commercial banks or other financial institutions working in the same field.

Table 4. Rate of return required with standard deviation, variance and coefficient of variation

\begin{tabular}{|l|l|l|l|l|l|}
\hline Bank name & $\begin{array}{l}\text { Coefficient } \\
\text { variation }\end{array}$ & $\begin{array}{l}\text { Variance and total } \\
\text { risk }\end{array}$ & $\begin{array}{l}\text { The required rate } \\
\text { of return }\end{array}$ & mean & S.D \\
\hline Jordan Islamic Bank & 0.28 & 0.00 & 0.16 & 0.25 & 0.07 \\
\hline Jordanian Kuwaiti & 0.73 & 0.02 & 0.08 & 0.18 & 0.13 \\
\hline Jordan Commercial & 0.99 & 0.08 & 0.01 & 0.28 & 0.27 \\
\hline Housing Bank & 0.32 & 0.00 & 0.02 & 0.07 & 0.02 \\
\hline Arab Investment & 0.79 & 0.06 & 0.10 & 0.32 & 0.25 \\
\hline Safwa Islamic & 1.51 & 25.80 & 0.03 & 3.36 & 5.08 \\
\hline the Union & 0.72 & 0.06 & 0.09 & 0.34 & 0.24 \\
\hline $\begin{array}{l}\text { Arab } \\
\text { Corporation }\end{array}$ & 0.12 & 0.01 & 0.31 & 0.34 \\
\hline Investment Bank & 1.10 & & & & \\
\hline Capital Bank & 0.34 & 0.01 & 0.09 & 0.24 & 0.08 \\
\hline Société & 1.93 & 15.58 & 0.08 & 2.05 & 3.95 \\
\hline Cairo Amman & 2.02 & 18.08 & 0.07 & 2.11 & 4.25 \\
\hline Jordan Bank & 0.97 & 0.11 & 0.12 & 0.35 & 0.34 \\
\hline Ahli Jordan & 0.50 & 0.01 & 0.11 & 0.25 & 0.12 \\
\hline Arab Bank & 0.89 & 0.04 & 0.05 & 0.23 & 0.21 \\
\hline Market Index & 0.68 & 0.01 & 0.07 & 0.14 & 0.10 \\
\hline
\end{tabular}


Table 5. Actual rate of return, required rate of return, standard deviation, variance, and variation factor for the optimal investment portfolio (2013-2017)

\begin{tabular}{|l|l|l|l|l|l|l|l|l|l|l|}
\hline Bank name & 2013 & 2014 & 2015 & 2016 & 2017 & mean & S.D & $\begin{array}{l}\text { Coefficient } \\
\text { of variation }\end{array}$ & $\begin{array}{l}\text { Variance } \\
\text { and } \\
\text { risk }\end{array}$ & $\begin{array}{l}\text { The } \\
\text { required } \\
\text { rate } \\
\text { return }\end{array}$ \\
\hline $\begin{array}{l}\text { Jordan Islamic } \\
\text { Bank }\end{array}$ & 0.35 & 0.16 & 0.20 & 0.27 & 0.17 & 0.25 & 0.07 & 0.28 & 0.00 & 0.16 \\
\hline $\begin{array}{l}\text { Jordanian } \\
\text { Kuwaiti }\end{array}$ & 0.36 & 0.25 & 0.25 & 0.18 & 0.07 & 0.18 & 0.13 & 0.73 & 0.02 & 0.08 \\
\hline $\begin{array}{l}\text { Jordan } \\
\text { Commercial }\end{array}$ & 0.18 & 0.15 & 0.14 & 0.27 & 0.04 & 0.28 & 0.27 & 0.99 & 0.08 & 0.01 \\
\hline Housing Bank & 0.09 & 0.09 & 0.07 & 0.06 & 0.03 & 0.07 & 0.02 & 0.32 & 0.00 & 0.02 \\
\hline Arab Investment & 0.62 & 0.40 & 0.13 & 0.13 & 0.15 & 0.32 & 0.25 & 0.79 & 0.06 & 0.10 \\
\hline the Union & 0.32 & 0.22 & 0.15 & 0.42 & 0.10 & 0.34 & 0.24 & 0.72 & 0.06 & 0.09 \\
\hline $\begin{array}{l}\text { Arab Banking } \\
\text { Corporation }\end{array}$ & 0.13 & 10.92 & 0.19 & 0.26 & 0.06 & 0.31 & 0.34 & 1.10 & 0.12 & 0.01 \\
\hline Investment Bank & 0.22 & 0.08 & 0.31 & 0.31 & 0.21 & 0.24 & 0.08 & 0.34 & 0.01 & 0.09 \\
\hline Cairo Amman & 0.20 & 0.12 & 0.26 & 0.95 & 0.15 & 0.35 & 0.34 & 0.97 & 0.11 & 0.12 \\
\hline Jordan Bank & 0.24 & 0.21 & 0.21 & 0.42 & 0.27 & 0.25 & 0.12 & 0.50 & 0.01 & 0.11 \\
\hline Ahli Jordan & 0.20 & 0.16 & 0.18 & 0.06 & 0.13 & 0.23 & 0.21 & 0.89 & 0.04 & 0.05 \\
\hline Arab Bank & 0.25 & 0.11 & 0.20 & 0.10 & 0.16 & 0.14 & 0.10 & 0.68 & 0.01 & 0.07 \\
\hline Market Index & 0.26 & 1.07 & 0.19 & 0.29 & 0.13 & 0.25 & 0.18 & 0.69 & 0.04 & 0.08 \\
\hline
\end{tabular}

Table 6. Correlations

\begin{tabular}{|c|c|c|c|c|c|c|}
\hline & & year1 & year2 & year3 & year4 & year5 \\
\hline & Pearson Correlation & 1 & $-.278-$ & $-.017-$ & $-.121-$ & .263 \\
\hline \multirow[t]{3}{*}{ year1 } & Sig. (2-tailed) & & .358 & .957 & 693 & .386 \\
\hline & $\mathrm{N}$ & 13 & 13 & 13 & 13 & 13 \\
\hline & Pearson Correlation & $-.278-$ & 1 & $-.011-$ & $-.038-$ & $-.298-$ \\
\hline \multirow[t]{3}{*}{ year2 } & Sig. (2-tailed) & .358 & & .972 & .903 & .322 \\
\hline & $\mathrm{N}$ & 13 & 13 & 13 & 13 & 13 \\
\hline & Pearson Correlation & $-.017-$ & $\mid-.011-$ & 1 & .451 & .538 \\
\hline \multirow[t]{3}{*}{ year3 } & Sig. (2-tailed) & .957 & .972 & & .122 & .058 \\
\hline & $\mathrm{N}$ & 13 & 13 & 13 & 13 & 13 \\
\hline & Pearson Correlation & $-.121-$ & $\mid-.038-$ & .451 & 1 & .275 \\
\hline \multirow[t]{3}{*}{ year4 } & Sig. (2-tailed) & .693 & .903 & .122 & & .364 \\
\hline & $\mathrm{N}$ & 13 & 13 & 13 & 13 & 13 \\
\hline & Pearson Correlation & .263 & $-.298-$ & .538 & .275 & 1 \\
\hline \multirow[t]{2}{*}{ year5 } & Sig. (2-tailed) & .386 & .322 & .058 & .364 & \\
\hline & $\mathrm{N}$ & 13 & 13 & 13 & 13 & 13 \\
\hline
\end{tabular}

The research results indicate that the commercial banks have succeeded in their estimates of the required or actual rate of return for the optimal investment portfolio banks. The matrix correlation between the returns on each bank in the investment portfolio is mostly low, which supports the confidence of the search efficiency with the contents of this portfolio of banks.

Markowitz's emphasis on the correlation between returns using diversification of portfolio stocks and its impact on the return and risk of each portfolio was achieved by forming an optimal investment portfolio that achieved high returns at a low level of risk. 


\section{Conclusion}

The above results show that the effective rate of return is higher than the required rate of return in the Jordanian commercial banks.

The study recommends the need to take a longer period of time and other financial assets such as bonds in future studies and the Jordanian banks to monitor the movements of competitors.

\section{References}

Al-Hasanat, R., \& Issa. (2013). Designing the optimal and alternative ordinary shares portfolio according to the beta model and the characteristics of the company and evaluating its performance - Amman Stock Exchange. Applied Study in Amman Stock Exchange. Amman Arab University. MDno.636838, pp. 249-1.

Ani, D. (2002). The Merger of International Financial Markets - Its Causes and Implications for World Economy, Baghdad. House of Wisdom, 2002.

Bodie, A. K., \& Marcus. (1990). Investments (4th. ed.). Irwin Mc Graw-hill.

Carlson, B., \& Charles. (1998). The individual investor Revolution. Mc Graw -Hill companies inc .

Chong, Y., \& Yee. (2004). Investment Risk management. John Wily and sons Ltd. https://doi.org/10.1002/9781118673324

Francis. \& Clark. (1991). Investment analysis and Management (5th ed.). MC Graw - hill inc.

Gholamreza, M. et al. (2010). A review on international portfolio diversification, African. Journal of Business Management, 4(19).

Houari. \& Malik. (2013). the impact of international diversification in the effective management of the financial Portfolios. Journal Researcher, 13.

Johnson, J. (2000). Global financial Institutions and Markets. First published 2000.

Mc, M., \& Jim. (1990). Financial Management. Christ Published by Routlege, 1990.

Michael, C. et al. (2005). Financial Management. Theory and Practice, thirteen edition 2005.

Robert, A., \& Hill. (2010). Portfolio theory and financial analysis. ISBN 978-87-7681-605-6.

Ross, A. et al. (1998). Fundamental of Corporate. Alternate, ed. MC - Grew Hill, companies, 1998.

Tamimi. \& Janabi. (2003). Designing the optimal and alternative common stock portfolio, an Applied Study in a Sample of Companies Listed on the Iraqi Stock Exchange. Administrative Technical College, 2001.

Weston. et al. (1998). Financial Theory And Corporate policy. Cassell Educational Limited, 1988.

\section{Copyrights}

Copyright for this article is retained by the author(s), with first publication rights granted to the journal.

This is an open-access article distributed under the terms and conditions of the Creative Commons Attribution license (http://creativecommons.org/licenses/by/4.0/). 